\title{
COST OF MUNICIPAL WATER TREATMENT PLANT IN THE BIGGEST POLISH TOWN IN PODLASKIE PROVINCE FOR THE YEARS 2010-2012
}

\author{
Agnieszka Kisło', Iwona Skoczko'
}

Department of Technology in Engineering and Environmental Protection, Faculty of Civil and Environmental Engineering, University of Technology in Bialystok, 45A Wiejska Str., 15-351 Bialystok, Poland, e-mail: agnieszka.kislo@wp.pl

Received: 2015.01.15

Accepted: 2015.02.08

Published: 2015.04.01

\begin{abstract}
In this paper the operation costs of the municipal water treatment plant in the biggest Polish town in Podlaskie province was analyzed. Capacity of this WTF is $600 \mathrm{~m}^{3} / \mathrm{h}$. Water treatment processes are primarily focused on removal of iron, mangnese and turbidity and disinfection by UV rays. Water is taken by 19 wells and then it is oxygenated. From aerators water is addressed to ten filters, which filter water at a speed of $8.5 \mathrm{~m} / \mathrm{h}$. The analysis of the operation costs of the municipal water treatment plant was carried out by a method of testing and interpretation of the materials provided by the Water and Sewerage Company in a big town in the Podlaskie Province. It was established that, groundwater treatment plant operation costs, carried out in 2010-2012, showed the highest share of depreciation and remuneration costs.
\end{abstract}

Keywords: underground waters, water treatment plant, operation costs analysis.

\section{INTRODUCTION}

Groundwater is water that lies beneath the Earth's surface at different depths, resulting from a variety of geological processes. Its total volume is approx. 60000 thousand $\mathrm{km}^{3}$, which is approx. $4.12 \%$ of the total volume of the Earth's hydrosphere resources [Chełmicki 2002].

The determinant of the usefulness of natural waters for a particular purpose is its physicochemical and bacteriological composition. Physico-chemical and bacteriological composition of groundwater is variable and depends on many factors, which include, inter alia, the contact time with the layers of rock, season of the year, the amount and quality of rainwater, and land cover [Nawrocki, Biłozór 2000].

Groundwater, due to its large resources and high quality, is a very important source of drinking water. Great economic importance and commonly occurring groundwater threat forces to maintain a quality control by organizing a groundwater monitoring system. Water to be safe for health must meet the parameters speci- fied in the Regulation of the Minister of Health of 20.04.2010 "The quality of water intended for human consumption" (Dz. U. No. 72, item. 466 dated 29.04.2010) [Regulation of the Minister of Health of 20.04.2010].

Today, the price of water contains a number of indirect costs, i.e.: the costs of its recognition, treatment and delivery to the recipient. The increase of water prices may be due to continuous modernization and introduction of new treatment technologies. This significantly improves the quality of water supplied to our homes. It should be also noted that the cost of "producing" water affect other factors, such as the cost of building water intake, water treatment technology, water transmission networks, as well as operating costs of these systems [Dąbrowski, Mountain2004; Dziembowski 1983].

Water whose parameters do not meet the legal requirements needs treatment. Nowadays level of technology and technical knowledge allow to treat even the most polluted waters. However, the process is economically inefficient if high pollution treatment costs grow disproportionately with 
the degree of water pollution. Economic considerations support the concept of water apprehension of the best quality. The treatment of most groundwater is limited to the reduction of the content of iron and manganese. Such a treatment is relatively simple technically [Heidrich 1985].

\section{METHODOLOGY}

In order to analyze the costs of the Municipal Water Treatment Plant (WTP) a method of testing and interpreting the materials provided by the Water and Sewerage Company in the big town in the Podlaskie Province was used. The data covered the period 2010-2012 and presented an overall picture of the financial operations of the Municipal Water Treatment Plant.

\section{DISCUSSION}

The most important operating costs of groundwater treatment plants include [Nawrocki, Biłozór 2000; Zadrożna 2011]:

- energy costs,

- salary related costs,

- costs of materials and repairs,

- the cost of installation of water meters,

- general and administrative costs,

- other costs.

In order to recognize the distribution of the various costs, the groundwater treatment plant (with a capacity of $600 \mathrm{~m}^{3} / \mathrm{h}$ ) was analyzed. The main problems of water quality are related to an extensive content of iron, manganese and turbidity. Therefore, the water treatment processes are primarily focused on removal of iron, mangnese and turbidity [The material provided by the Water and Sewage in Suwałki].

Water is taken by 19 wells. Its treatment technology at the WTP is as follows: from the well the water is addressed to two pressure reaction chambers. There the water is oxygenated using compressed air supplied by three oil-free compressors. The objective of aeration is to introduce oxygen into the water to allow the partial oxidation of iron and manganese from the form of $\mathrm{Fe}^{2+}$ and $\mathrm{Mn}^{2+}$ to the form of $\mathrm{Fe}^{3+}$ and $\mathrm{Mn}^{4+}$ and their primary precipitation. Water aeration allows also its de-acidification. Crowding undissolved gas is run by automatic valves. From aerators the water is addressed to ten filters, with filtration rate of
$8.5 \mathrm{~m} / \mathrm{h}$. The filters are filled with a fluid layered "CULSORB M" and work fully automatically thanks to programmable controllers, dampers and diaphragms. Behind the filters, water is collected in four reservoir's tanks of clean water with a total capacity of $9600 \mathrm{~m}^{3}$. Clean water tanks provide water supply to compensate for uneven hourly partitions. From the tanks, equipped with dual air filtration system, water flows by gravity into the pumps' hall. Next it meets continuous UV disinfection lamp and goes to recipients using horizontal pumps.

Water treatment plant provides treated water to almost $100 \%$ of the town's population (70 thous.). The total length of the water supply network in the studied city (connections) is $214.5 \mathrm{~km}$. Yearly WTP produces about 3 million $\mathrm{m}^{3}$ of water (approx. 8 thousand. $\mathrm{m}^{3}$ per day) and sales approx. 2.5 million $\mathrm{m}^{3}$. Water $\left(2\right.$ million $\left.\mathrm{m}^{3}\right)$ is supplied mainly to households. Approx. 60 thousand. $\mathrm{m}^{3}$ of water is spent for production [Documentation hydrogeological... 1993].

Total cost of Municipal Water Treatment Plant include the following types of costs:

- depreciation,

- fuel costs,

- costs of oil,

- costs of consumables,

- costs of materials for repairs,

- costs of electricity consumption,

- costs of thermal energy,

- the costs of transport services,

- the costs of conservation and modernization,

- the costs of other services,

- salaries,

- social security,

- employees' benefits,

- taxes and fees,

- the costs of business trips,

- the cost of banking services,

- the costs of representation and advertising,

- other costs,

- settlement costs.

Figure 1 shows that, the largest share in total cost of ownership of groundwater treatment plant are depreciation costs (45.40-47.10\%) and expenses (19.7\%). The lowest part is the cost of fuel $(0.01-0.04 \%)$. Analyzing the cost statement for the period 2010-2012 for the Water Treatment Plant, the authors have noted a gradual increase in operating costs over the years. It can be assumed that this relationship is caused by the increase of 
2010

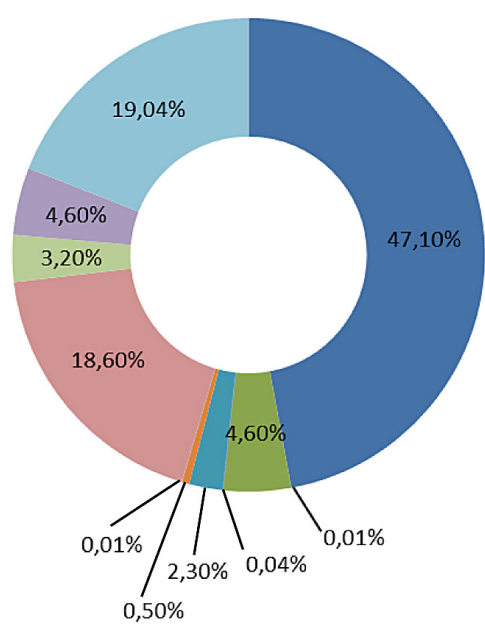

2011

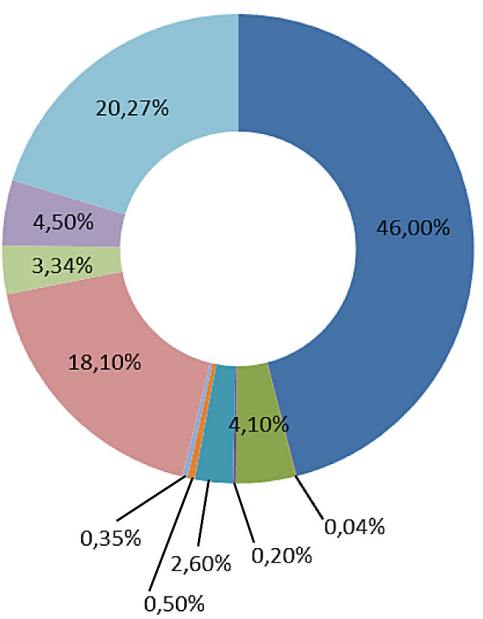

2012

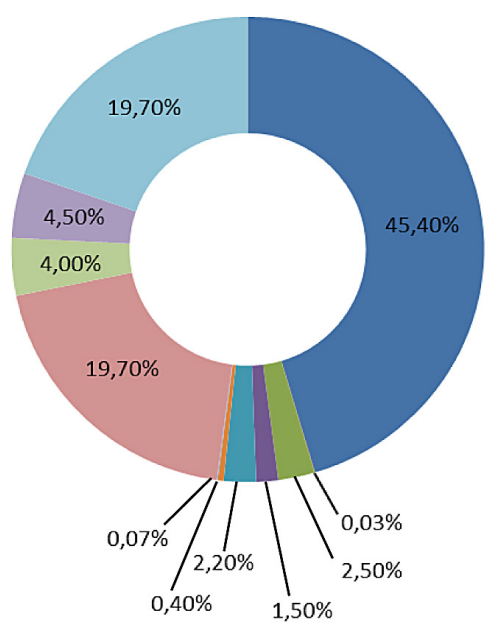

घ depreciation

a fuel costs

costs of consumables

n costs of materials for repairs

a costs of electricity

consumption

u costs of thermal energy

the costs of repair

口 salaries

घocial security

$\square$ taxes and fees

ather costs

ndepreciation

$\square$ fuel costs

costs of consumables

u costs of materials for repairs

- costs of electricity

consumption

a costs of thermal energy

the costs of repair

a salaries

$\square$ social security

- taxes and fees

$\square$ other costs

a depreciation

$\square$ fuel costs

costs of consumables

n costs of materials for repairs

a costs of electricity

consumption

a costs of thermal energy

the costs of repair

口 salaries

घocial security

$\square$ taxes and fees

other costs

Figure 1. Percentage of individual costs' share in relation to the total outlays of the Water Treatment Plant in 2010-2012 


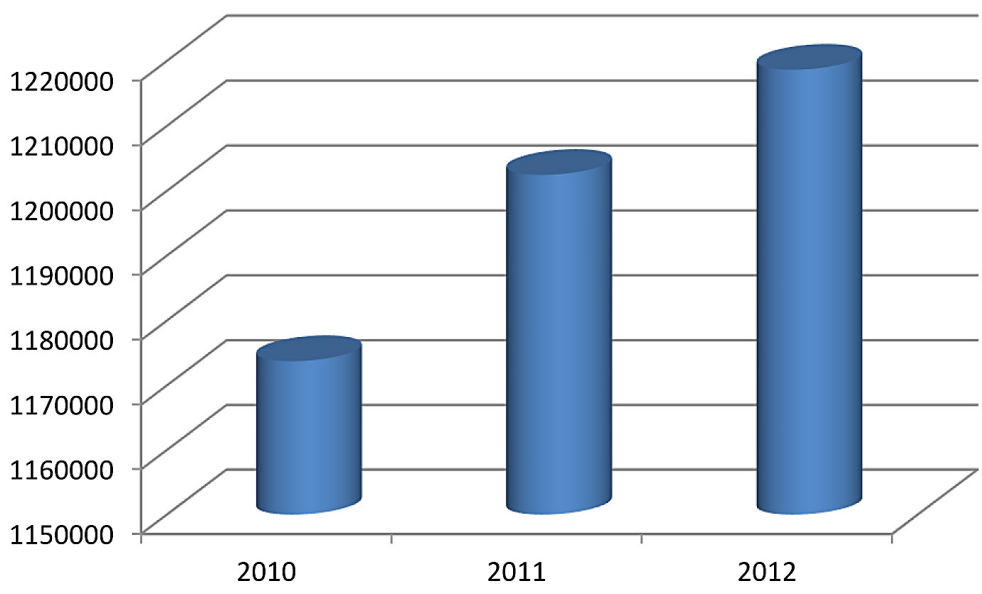

Figure 2. Graph of the changes in the total annual outlays of the Water Treatment Plant in the big city in the Podlaskie Province in 2010-2012

market prices and the cost of maintenance of the facilities. Over the three analyzed years (20102012) the WTP management decided to make only one quite expensive conservation (Figure 2). Therefore, it can be concluded that the groundwater treatment plant is characterized by high operational reliability.

\section{CONCLUSIONS}

On the basis of the analyzed materials the authors have found that the processes used in Municipal Water Treatment Plant allowed for reduction of iron, manganese and turbidity from the treated water to the required level. The largest share of total operating costs of groundwater treatment station are depreciation costs and the costs of wages. The studied WTP is characterized by low fuel costs. The increase of the market price of energy and materials used for water treatment caused an increase in total cost of ownership of underground water treatment station in Suwałki in $2010-2012$ by about $5 \%$.

\section{REFERENCES}

1. Chełmicki W. 2002. Water: resources, degradation, protection. PWN, Warsaw.
2. Dąbrowski S., Mountain J. 2004. Methodology for determining the reserves of fresh groundwater intakes. Ministry of the Environment, Warsaw.

3. Dziembowski Z 1983. Municipal enterprise economics. PWE, Warsaw.

4. Heidrich Z. 1985. Technical and economic aspects of water treatment. Environment, ed. PZITS, Wroclaw.

5. Nawrocki J., Biłozór S. 2000. Water treatment. Chemical and biological processes. PWN, Warsaw-Poznan.

6. Weber L. 2010. Exploitation of underground water treatment station. Part I. Types and operation of aeration systems underground water pressure. Water Technology, 1(3).

7. Weber L. 2010. Exploitation of underground water treatment station. Part IV. Checking the condition of filter beds. Water Technology, 4(6).

8. Zadrożna S. 2011. Evaluation of groundwater treatment technologies for the chosen example. Thesis Engineering. University of Bialystok, Bialystok.

9. Documentation hydrogeological groundwater resources area Suwałki. Department of Service Design "Eco-Geo" M. Tatarata in Suwałki. Suwałki 1993.

10. Regulation of the Minister of Health of 20.04.2010 on the quality of water intended for human consumption (Dz. U. No. 72, item. 466 dated 29.04.2010).

11. The material provided by the Water and Sewage in Suwałki. Website www.pwik.suwalki.pl 